\title{
DETERMINANT OF INDEPENDENT NATIONAL HEALTH INSURANCE OWNERSHIP IN INDONESIA
}

\author{
Bela Sari ${ }^{1}$ and Haerawati Idris ${ }^{2^{*}}$ \\ 1,2 Department of Health Policy and Administration, Faculty of Public Health, Universitas Sriwijaya, \\ Indralaya, Ogan Ilir, South Sumatera 30662 Indonesia \\ *Correspondence author: Haerawati Idris \\ Email: haera@fkm.unsri.ac.id
}

\begin{abstract}
The increasing of Independent National Health Insurance (NHI) membership is one of the indicators to achieve Universal Health Coverage. One of the challenges in extending such coverage is reaching it out to the informal sector. This study was aimed to analyze the determinants of Independent NHI ownership in Indonesia. This study used cross-sectional design, and the data were derived from Indonesian Family Live Survey (IFLS) 2014. 6,888 individuals aged $\geq 40$ years were the sample of this study. To analyze the data, chi-square analysis and logistic regression were used. Based on the analysis, the proportion of respondent with Independent $\mathrm{NHI}$ is $16.6 \%$. The ownership of independent $\mathrm{NHI}$ is influenced by the following factors: age 40-55 $(P R=1.7295 \% \mathrm{Cl} 1.41-2.09$, $p$-value $<0.001)$, Sumatra Island $(P R=7.6795 \% \mathrm{Cl} 5.55-10.59 \mathrm{p}$ value $<0.001)$, very rich $(P R=2.2695 \% \mathrm{Cl} 1.85-2.75 p$-value $<0.001)$, history of chronic disease $(P R=1.3395 \% \mathrm{Cl} 1.15-1.53 p$ value $<0.001)$, junior high school $(P R=2.2195 \% \mathrm{Cl} 1.92-2.55 p$-value $<0.001)$, and urban $(P R=1.7995 \% C l 1.57-2.04 p$-value $<0.001$ ). Region is the most dominant variable related to $\mathrm{NHI}$ ownership ( $p$-value $<0.001$; Exp $B=7.03$; 95\% Cl: 5.06-9.77). Independent NHI membership has not been maximal, yet. To increase this participation, the Social Security Administrator should approach each region with low NHI membership through promotion, socialization, and education about registration and the benefits of independent $\mathrm{NHI}$.
\end{abstract}

Keywords: National Health Insurance, Informal Sector, Indonesian Family Life Survey

\section{INTRODUCTION}

A major issue of public health concern for governments and international health organizations around the world is the challenge of health care financing. For most countries, this challenge is caused by a weak policy to finance health care. The recommended strategies for addressing issues related to international health policy, one of which the government implements various interventions including health insurance policies to improve the health of its inhabitants ${ }^{1,2}$.

A large proportion of the informal sector is a common feature found in many developing countries. Indonesia is one of the countries targeting Universal Health Coverage in 2019. In this decade, there were most informal sectors in Indonesia; that's roughly between 60 and $70 \%$ of all workers ${ }^{3}$. The goal of UHC (Universal Health Coverage) itself is to ensure that every citizen in the population has fair access to quality health services including preventive, curative and rehabilitative. In Indonesia, a program held by government to reach UHC is known as National Health Insurance (Jaminan Kesehatan Nasional, or $J K N$ ). National health insurance is organized by the Social Security Administrator (Badan Penyelenggara Jaminan Sosial, or BPJS). NHI is part of the National Social Security System (Sistem Jaminan Sosial Nasional, or SJSN) with the mechanism of social health insurance. NHI is mandatory from Law Number 40 the Year 2004 regarding National Social Security System ${ }^{4}$.

The objective of national health insurance is that all Indonesians are protected in an insurance system and to meet the basic public health needs provided by everyone who has paid contributions or fees paid by the government. The essence of insurance is to distribute risks/hazards 5 . Those who pay contributions from self-employed workers are called as independent participants ${ }^{6}$. For people with a good level of the economy, it is not a problem of costly expenses to get optimal health services, but if the problem is experienced in people with low economies that cannot cost to obtain health services, the absence of health insurance becomes a trap of poverty and even death ${ }^{7}$.

Based on the National Health Insurance road map 2012-2019, Non-Wage Earners (Pekerja Bukan Penerima Upah, or PBPU) or Self-Employed workers are the realms of informal sector workers. Increased participation and expansion of the informal sector is required to achieve universal coverage or Universal Health Coverage (UHC). 
Based on the data of operational web page of the Social Security Administrator (SSA) of Health, nationally records that the number of SSA of health participants by October 28 2016, is 170,213,981 and the number of participants in $\mathrm{NHI}$ program dominated by APBN Beneficiaries (Penerima Bantuan luran, or PBI) is $53.55 \%$ of the total membership, while the percentage of participation from Non-Wage Earners or Self-Employee workers reach $11.10 \%$ of the total membership. This means that informal sector workers are still not participating in the National Health Insurance scheme while increasing and expanding participation from the informal sector is required to achieve $\mathrm{UHC}^{8}$.

The Indonesian nation intends to address various issues related to health care costs and the quality of health services; therefore, the government makes efforts to increase the coverage of this membership?. The purpose of this study was to analyze the determinant factors affecting the ownership of the Independent National Health Insurance (NHI) in Indonesia.

\section{METHODS}

The design of this study was cross-sectional. The type of data used in this study was secondary data obtained from the Indonesian Family Life Survey (IFLS) in 2014. IFLS is the most comprehensive household longitudinal survey ever conducted in Indonesia. IFLS is also a longitudinal survey on socio-economic and health and aims to provide a sustainable picture of the socio-economic and health conditions of households in Indonesia ${ }^{10}$.

The analysis methods used were chi-square analysis and logistic regression. The population in this study was all respondents in Indonesia that stay at 13 provinces: four provinces on Sumatra (North Sumatra, West Sumatra, South Sumatra, and Lampung), all five of the Javanese provinces (DKI Jakarta, West Java, Central Java, DI Yogyakarta, and East Java), and four provinces covering the remaining major island groups (Bali, West Nusa Tenggara, South Kalimantan, and South Sulawesi) representing Indonesia who are appropriate and successfully interviewed by IFLS team in 2014.

The sample of study focused and conducted for the respondents who are more than 40 years old. We consider it because they have more history of chronic disease and more susceptible to the degenerative disease. The number of people who participated in IFLS 2014 was 50,579 people. After excluding Samples who have age below 40 years old and those respondents with missing data. 6,888 respondents were included for analysis.
This study had a dependent variable; Independent $\mathrm{NHI}$ ownership. Independent variables which were age, sex, region, economic status, history of chronic disease, education background, region, residency, self-reported, and job status. The region is defined as respondents grouped by geographic area or province and are divided into three namely Java/Bali, Sumatra \& East Region. The economic status variable is defined as the amount of household expenditure for the cost of food consumption, non-food costs consisting of the cost of equipment and the needs of household members, the cost of education, electricity, water, economic status which are grouped based expenditure per month to Q1 = very poor, Q2 = poor, $\mathrm{Q} 3=$ middle, $\mathrm{Q} 4=$ rich, and $\mathrm{Q} 5=$ very rich. The history of chronic disease is defined as the condition/disease diagnosed by doctors/paramedics/nurses/midwives such as hypertension, diabetes, TBC, asthma, heart, lungs, liver, stroke, cancer/tumor in the last 4 weeks. While education background is defined as the last formal school level that has been rescued by the respondent with the criteria of (no school, elementary school), (Junior and Senior High Schools), and High (Diploma+) Education is measured by observation of the last diploma owned by individu ${ }^{11}$. Residency variable is a description of the respondents related to residential areas with rural or urban options. Selfreported as self-rated of health respondent divided into healthy and unhealthy.

Data collection is obtained using the 2014 IFLS through the Survey Meter and can be accessed through the official IFLS website rand http://www.rand.org/labor/FLS/IFLS/download.ht $\mathrm{ml}$.Ethical clearance for this study was received from the Ethics Committee of faculty of public health, Sriwijaya University ID.64/UN9.1.10/KKE/2018.

\section{RESULTS}

Based on the descriptive result (Table 1), the number of respondents who have $\mathrm{NHI}$ is $16.6 \%$, the majority of female respondents are $51.0 \%$, age 40 55 is $64.4 \%$, who live in Java Bali is $65.9 \%$, who have very rich is $24.4 \%$, who have no history of chronic disease is $86.9 \%$, who have low education is $50.4 \%$, who live in urban area of $66.0 \%$, selfreported as unhealthy is $70.2 \%$, and have an informal employment status $58.5 \%$. 
Table 1. Socio-demographic characteristics of the participants

\begin{tabular}{|c|c|c|}
\hline Variable & $\mathrm{n}(6,888)$ & $\%$ \\
\hline $\begin{array}{l}\text { Independent } \quad \mathrm{NHI} \\
\text { Ownership }\end{array}$ & & \\
\hline Yes & 1,141 & 16.6 \\
\hline No & 5,747 & 83.4 \\
\hline \multicolumn{3}{|l|}{ sex } \\
\hline Male & 3,372 & 49 \\
\hline Female & 3,516 & 51 \\
\hline \multicolumn{3}{|l|}{ Age } \\
\hline $40-55$ & 4,433 & 64.4 \\
\hline $56-65$ & 1,336 & 19.4 \\
\hline$>65$ & 1,119 & 16.2 \\
\hline \multicolumn{3}{|l|}{ Region } \\
\hline Sumatera & 1,320 & 19.2 \\
\hline Java \& Bali & 4,536 & 65.9 \\
\hline East Indonesia & 1,032 & 15 \\
\hline \multicolumn{3}{|l|}{ Economic status } \\
\hline $1^{\text {st }}$ (Very Poor) & 1,483 & 21.5 \\
\hline $2^{\text {nd }}$ (Poor) & 1,220 & 17.7 \\
\hline $3^{\text {rd }}$ (Middle) & 1,247 & 18.1 \\
\hline $4^{\text {th }}$ (Rich) & 1,257 & 18.2 \\
\hline $5^{\text {th }}$ (Very Rich) & 1,681 & 24.4 \\
\hline \multicolumn{3}{|l|}{$\begin{array}{l}\text { Chronic Disease } \\
\text { History }\end{array}$} \\
\hline Yes & 899 & 13.1 \\
\hline No & 5,989 & 86.9 \\
\hline \multicolumn{3}{|l|}{ Educational } \\
\hline Elementary School & 3,472 & 50.4 \\
\hline $\begin{array}{l}\text { Junior-senior high } \\
\text { school }\end{array}$ & 2,414 & 35 \\
\hline $\begin{array}{l}\text { High school } \\
\text { Residency }\end{array}$ & Residency & 14.5 \\
\hline Urban & 4,548 & 66 \\
\hline Rural & 2,340 & 34 \\
\hline \multicolumn{3}{|l|}{ Self-reported } \\
\hline Healthy & 2,052 & 29.8 \\
\hline Unhealthy & 4,836 & 70.2 \\
\hline Job Status & 4,029 & 58.5 \\
\hline Formal & 2,859 & 41.5 \\
\hline
\end{tabular}

Bivariat analysis shows the relationship between independent national health insurance ownership and independent variable (table 2 ). Men have a higher proportion of health insurance ownership than women. Respondents who have the age of 40 55 years have highest proportion in the ownership of health insurance. Respondents who live in Sumatra have a higher proportion of health insurance ownership compared to Bali and eastern region. Proportion of health insurance ownership Increasing among economic status of respondent. Respondents who have a history of chronic illness are more likely to have health insurance than respondents who do not have a history of chronic illness. Based on the education background, ownership of health insurance dominates respondents who have junior-senior school. Respondents who live in urban have higher proportion to have health insurance than respondents who live in rural areas. Respondents who have self reported as healthy, have higher health insurance than unhealthy. Respondents with informal employment status have more health insurance than respondents who have formal employment. The results of the analysis shows that age, region, economic status, education level, history of chronic diseases, and residency, have a significant relationship with the ownership of independent health insurance significantly ( $\mathrm{p}$-value $<0.05$ )

Table 3 shows that multivariate analysis results are significantly associated with ownership of Independent NHI i.e. age, region, economic status, history of chronic disease, education background, residence, and health status. Based on the above table, it shows that the most dominant variable affecting the ownership of Independent $\mathrm{NHI}$ in Indonesia is a region after controlled by other variables. The results of the analysis above show that the region variable with the greatest PR value is $7.03(95 \% \mathrm{Cl} 5.06-9.77)$ which means that respondents who live in Sumatra island have a chance 7.03 times greater to have Independent $\mathrm{NHI}$ compared to respondents who live in the eastern part of Indonesia with a range of values from 5.06 to 9.77 .

\section{DISCUSSION}

This study aims to analyse the determinant of ownership of Independent $\mathrm{NHI}$ in Indonesia. Descriptive results indicate that the membership of Independent NHI is only $16.6 \%$. The ownership of Independent $\mathrm{NHI}$ is influenced by the following factors: age, region, economic status, history of chronic diseases, education, and residency. The result of the analysis shows that the majority of respondents who have Independent $\mathrm{NHI}$ are respondents who are 40-55 years. A person's age can describe a person's maturity in determining the action of life. The more aged the respondent increases the more mature they are in determining an option included in the selection of health insurance ${ }^{12}$. The study is aligned based on A previous study ${ }^{13}$. The probability for health insurance schemes contributed to increased contributions with age ${ }^{14}$. According to Grossman's theory, as health supplies decline with age, older people will invest more than younger people ${ }^{15}$. Economic theory predicts that an increase in one's age will lead to a decline in health conditions in addition to an increase in value (a manifestation of aging biological processes) and they maintain health by investing in health through health insurance to reduce the value ${ }^{16}$. 
Table 2. Bivariate Analysis of Independent National Health Insurance Ownership

\begin{tabular}{|c|c|c|c|c|c|}
\hline \multirow[t]{2}{*}{ Variable } & \multicolumn{2}{|c|}{ Independent NHI Ownership (\%) } & \multirow[t]{2}{*}{ P-Value } & \multirow[t]{2}{*}{$\overline{P R}$} & \multirow[t]{2}{*}{$\mathrm{Cl} 95 \%$} \\
\hline & Yes & No & & & \\
\hline \multicolumn{6}{|l|}{$\operatorname{sex}$} \\
\hline Male & $587(17.4)$ & $2,785(82.6)$ & 0.070 & 1.10 & $0.994-1.228$ \\
\hline Female & $554(15.8)$ & $2,962(84.2)$ & & Ref & \\
\hline \multicolumn{6}{|l|}{ Age } \\
\hline $40-55$ & $829(18.7)$ & $3,604(81.3)$ & $<0.001$ & 1.72 & $1.413-2.094$ \\
\hline $56-65$ & $180(13.5)$ & $1,156(86.5)$ & 0.214 & 1.16 & $0.916-1.480$ \\
\hline$>65$ & $132(11.8)$ & $987(88.2)$ & $<0.001$ & ref & \\
\hline \multicolumn{6}{|l|}{ Region } \\
\hline Sumatera & $342(25.9)$ & $978(74.1)$ & $<0.001$ & 7.67 & $5.552-10.596$ \\
\hline Java \& Bali & $754(16.6)$ & $378(83.4)$ & $<0.001$ & 4.37 & $3.211-5.955$ \\
\hline East Indonesia & $45(4.4)$ & $987(95.6)$ & $<0.001$ & Ref & \\
\hline \multicolumn{6}{|l|}{ Economic status } \\
\hline $1^{\text {st }}$ (Very Poor) & $167(11.3)$ & $1,316(88.7)$ & $<0.001$ & Ref & \\
\hline $2^{\text {nd }}$ (Poor) & $167(13.7)$ & $1,053(86.3)$ & 0.057 & 1.25 & $0.994-1.572$ \\
\hline $3^{\text {rd }}$ (Middle) & $193(15.5)$ & $1,054(84.5)$ & 0.001 & 1.44 & $1.155-1.802$ \\
\hline $4^{\text {th }}$ (Rich) & $239(19.0)$ & $1,018(81)$ & $<0.001$ & 1.85 & $1.494-2.291$ \\
\hline $5^{\text {th }}$ (Very Rich) & $375(22.3)$ & $1,306(77.7)$ & $<0.001$ & 2.26 & $1.857-2.757$ \\
\hline \multicolumn{6}{|c|}{ Chronic Disease History } \\
\hline Yes & $190(21.1)$ & $709(78.9)$ & $<0.001$ & 1.33 & $1.158-1.530$ \\
\hline No & $951(15.9)$ & $5,038(84.1)$ & & Ref & \\
\hline \multicolumn{6}{|c|}{ Educational Background } \\
\hline Elementary school & $399(11.5)$ & $3,073(88.5)$ & $<0.001$ & Ref & \\
\hline Junior high school & $540(22.4)$ & $1,874(77.6)$ & $<0.001$ & 2.21 & $1.926-2.557$ \\
\hline High school & $202(20.2)$ & $800(79.8)$ & $<0.001$ & 1.94 & $1.614-2.343$ \\
\hline \multicolumn{6}{|l|}{ Recidency } \\
\hline Urban & $887(19.5)$ & $3,661(80.5)$ & $<0.001$ & 1.79 & $1.577-2.047$ \\
\hline \multirow{3}{*}{$\begin{array}{l}\text { Rural } \\
\text { Self-reported } \\
\text { Healthy }\end{array}$} & $254(10.9)$ & $2,086(89.1)$ & & Ref & \\
\hline & & & & & \\
\hline & $365(17.8)$ & $1,687(82.2)$ & 0.081 & 1.11 & $0.990-1.241$ \\
\hline \multirow{4}{*}{$\begin{array}{l}\text { Unhealthy } \\
\text { Job Status } \\
\text { Informal } \\
\text { Formal }\end{array}$} & $776(16.0)$ & $4,060(84.0)$ & & Ref & \\
\hline & & & & & \\
\hline & $689(17.1)$ & $3340(82.9)$ & 0.165 & 1.08 & $0.970-1.206$ \\
\hline & $452(15.8)$ & $2407(84.2)$ & & Ref & \\
\hline
\end{tabular}

The results of the analysis state that the majority of respondents who have $\mathrm{NHI}$ are the respondents who live in Sumatra Island. Regional variables are the variables associated with ownership of an Independent NHI. This region variable is a variable that has a significant relationship and is the most dominant variable to the Independent $\mathrm{NHI}$ ownership for it has the greatest PR value of 7.39 which means that respondents who live in Sumatra Island are more likely to have Independent NHI compared with the respondents who live in eastern Indonesia. This study is in line with previous research which states that the region variable is the variable that influences the ownership of the $\mathrm{NHI}{ }^{16}$.

The result of the bivariate analysis shows the highest proportion to have Independent $\mathrm{NHI}$ are the respondents with very rich $(22.3 \%)$. The people who have money can pay the premium of health insurance. This finding is line with a study conducted a study mentioned that monthly income and expenditure have a significant relationship to the regularity of contributions payment on Independent $\mathrm{NHI}$ participants ${ }^{17}$. Health status is an important determinant of income and the capacity to enjoying life. A decrease in the mortality rate at working age may increase the earnings prospects by extending the period when income is received ${ }^{18}$. Earnings are closely related to education and employment. A society with a high level of education usually can get a job in the formal sector, which can provide health insurance and better income levels. High-income residents, with their own awareness, will use health insurance for themselves and their families ${ }^{19}$. 
Table 3. Factors that associated with independent national health insurance

\begin{tabular}{lcc}
\hline Variable & P-Value & PR(95\%Cl) \\
\hline Age 40-55 & $<0.001$ & $1.572(1.273-1.941)$ \\
Age 56-65 & 0.841 & $1.026(0.800-1.315)$ \\
Age $>65$ & $<0.001$ & - \\
Sumatra & $<0.001$ & $7.037(5.068-9.771)$ \\
Java \& Bali & $<0.001$ & $4.164(3.046-5.692)$ \\
East Indonesia & $<0.001$ & - \\
Very rich & $<0.001$ & $0.575(0.462-0.716)$ \\
rich & $<0.001$ & $0.653(0.526-0.810)$ \\
middle & 0.001 & $0.704(0.574-0.863)$ \\
poor & 0.063 & $0.836(0.692-1.010)$ \\
Very poor & $<0.001$ & - \\
Chronic Disease & 0.003 & $0.747(0.621-0.904)$ \\
Junior-senior high school & 0.002 & $0.701(0.562-0.874)$ \\
High school & 0.231 & $1,127(0,927-1,372)$ \\
Elementary school & $<0.001$ & - \\
Residency & $<0.001$ & $0.606(0.516-0.711)$ \\
Self reported & 0.004 & $0.804(0.693-0.933)$ \\
Job Status & 0.006 & $0.817(0.708-0.942)$ \\
\hline
\end{tabular}

The results of the analysis show that the majority of respondents who have an opportunity to have Independent $\mathrm{NHI}$ of respondents who have a history of chronic diseases. This study is in line with research conducted which claims that factor related to voluntary insurance ownership is a history of chronic disease ${ }^{20}$. Based on the results of the analysis, it is known that there is a relationship between the history of chronic diseases and the ownership of commercial health insurance. Someone who thinks that he/she has a history of chronic disease will choose to become a participant of the NHI since they are experienced and feel that one day if the disease relapses, they will suffer and more frequently use health services, if they do not have $\mathrm{NHI}$, it is very possible that expenses to be incurred for treatment will be very expensive.

Education is a strong predictor of insurance determinants because it will increase access to job benefits with higher incomes ${ }^{21}$. According to a study found that the level of formal education has influenced people's thinking processes. Formal education affects health. Someone with higher education has a higher demand. Higher education will raise awareness of the importance of health insurance. Highly-educated people consider the importance of health, thus ensuring that their health is administered by public institutions rather than poorly-educated communities ${ }^{22}$. A system, educational and religious institutions have a strong influence in the formation of attitudes because they laid the foundations of understanding and moral concepts in individuals ${ }^{23}$.
The analysis shows that education variables have a significant relationship with Independent $\mathrm{NHI}$ ownership. The majority of middle-educated respondents are more likely to have Independent NHI. This research is in line with a study which shows that education has influenced the community in the participation of Independent $\mathrm{NHI}$. Low-educated people have a 7.5 time risk of not being Independent NHI participants versus highly educated people.6 Consistent with Maharani's study, there is a significant relationship between the educational interest of having unitlink Insurance Program (Health Insurance), in line with the results of a study which states that education and income are important determinants both in demand for health services and the decision to have insurance ${ }^{24}$. The results show that respondents who live in urban areas are more likely to have Independent NHI than those in rural areas. There is a significant relationship between the residential area and the ownership of $\mathrm{NHI}$ in Indonesia in 2014. This research is in line with research that reported individual who stay in urban more likely to have health insurance than rural ${ }^{16}$.

Independent $\mathrm{NHI}$ membership has not been maximal.

The Indonesian government needs to expand the coverage of contributory health insurance by providing better ways to reach informal sector workers $^{25}$. A new approach should be done by Social Security Administrator of Health for improving the coverage. 


\section{CONCLUSION}

This study looks at the factors affecting the ownership of Independent $\mathrm{NHI}$ in Indonesia. The results show that age, region, history of chronic disease, economic status, education, and residency have a significant relation with Independent $\mathrm{NHI}$ ownership. The region is the most dominant variable affecting ownership of Independent $\mathrm{NHI}$ with a value of $\operatorname{Exp}(B)=7.03$ after controlled by other variables. Independent $\mathrm{NHI}$ membership in Indonesia has not been maximized. To increase this participation Social Security Administrator of Health should approach to each region with low $\mathrm{NHI}$ membership through promotion, socialization, and education about how to register and the benefits of independent NHI.

\section{REFERENCES}

1. Kumi-Kyereme A, Amu H, Darteh EK. Barriers and motivations for health insurance subscription in Cape Coast, Ghana: a qualitative study. Archives of Public Health. 2017 Dec;75 (1):24.

2. Todaro MP, Smith SC. Economic development. Harlow. 2006

3. Nazara S. Ekonomi Informal di Indonesia: Ukuran, komposisi dan evolusi. ILO; 2010.

4. Rivany R. Quo Vadis Undang-undang Sistem Jaminan Sosial Nasional?. Jurnal Manajemen Pelayanan Kesehatan. 2010 Sep; 13 (03).

5. Boni JA, Denning EM, Finley M, Lowe TR, Peskowitz BE. The Health Insurance Primer-An Introduction to How Health Insurance Works. Health Insurance Association of America. 2000:2-5.

6. Surya E, Yunita J. Community Participation into the National Social Health Insurance Independently.conference proceeding. International Meeting of Public Health (IMOPH). University of Indonesia. 2016

7. Carolina P, Fraditha A, Paskaria I. Hubungan Tingkat Pengetahuan dengan Sikap Keluarga Menggunakan Jaminan Kesehatan Nasional di Wilayah Kerja UPTD Puskesmas Pahandut Kota Palangka Raya. Dinamika Kesehatan Jurnal Kebidanan dan Keperawatan. 2016 Jul 15;7(1):218-23.

8. Badan Penyelenggara Jaminan Sosial Kesehatan. Jumlah peserta Jaminan Kesehatan Nasional per 28 Oktober 2016. www.bpjs kesehatan.go.id/bpjs/ (accessed 2 November 2016)

9. Endartiwi ss, Trisnantoro l, Hendrartini y. Dampak kebijakan kepesertaan mandiri jaminan kesehatan nasional (jkn) di yogyakarta. Jurnal kesehatan masyarakat. 2017;10(1).

10. Strauss J, Witoelar F, Sikoki B, Wattie AM. The fourth wave of the Indonesia Family Life Survey: Overview and field report. 2009.

11. Maharani NP, Zukhri A, Suwena KR. Analisis Faktor-faktor yang mempengaruhi masyarakat di kota singaraja memiliki program asuransi unitlink. Jurnal Pendidikan Ekonomi Undiksha. 2015 Mar 29; 5(1).

12. Tiaraningrum R. Studi Deskriptif Motivasi dan Personal Reference Peserta JKN Mandiri pada Wilayah Tertinggi di Kelurahan Mojosongo Kota Surakarta (Doctoral dissertation, Universitas Muhammadiyah Surakarta). 2014.

13. Littik S. Faktor-faktor yang berhubungan dengan Kepemilikan Asuransi di Provinsi Nusa Tenggara Timur. Jurnal MKM. 2007 Dec;3(02).

14. Kirigia JM, Sambo LG, Nganda B, Mwabu GM, Chatora R, Mwase T. Determinants of health insurance ownership among South African women. BMC health services research. 2005 Dec;5(1):17.

15. Grossman M. On the concept of health capital and the demand for health. Journal of Political economy. 1972 Mar $1 ; 80(2): 223-55$.

16. Idris $H$, Satriawan E, Trisnantoro $L$. Determinant of health insurance ownership in the informal sector: a panel study from Indonesia family life survey. Advanced Science Letters. 2017 Apr 1;23(4):3582-5.

17. Pratiwi AN. Faktor yang Mempengaruhi Keteraturan Membayar luran Pada Peserta Jaminan Kesehatan Nasional (Jkn) Kategori Peserta Mandiri (Studi Kasus Pasien Rawat Inap Rumah Sakit dr. Soebandi Kabupaten Jember).2016.www.repository.unej.ac.id/ handle/123456789/73502(accessed 26 June 2019). 
18. Kimani JK, Ettarh R, Warren C, Bellows B. Determinants of health insurance ownership among women in Kenya: evidence from the 2008-09 Kenya demographic and health survey. International journal for equity in health. 2014 Dec;13(1):27.

19. Rohmawati D. Hubungan pengetahuan sikap dan sosial ekonomi dengan pemilihan jenis iuran keikutsertaan JKN mandiri pada wilayah cakupan JKN tertinggi di Surakarta (Doctoral dissertation, Universitas Muhammadiyah Surakarta). 2014.

20. Intiasari AD, Trisnantoro L, Hendrartini J. Potret masyarakat sektor informal di Indonesia: kesehatan sebagai upaya perluasan kepesertaan pada skema non PBI mandiri. Jurnal Kebijakan Kesehatan Indonesia. 2015;4(4):126-32.

21. Montez JK, Angel JL, Angel RJ. Employment, marriage, and inequality in health insurance for Mexican-origin women. Journal of health and social behavior. 2009 Jun;50(2):132-48.

22. Noviansyah K, Dewi FS. Persepsi masyarakat terhadap program jaminan kesehatan bagi masyarakat miskin. Berita kedokteran masyarakat. 2006;22(2006).

23. Saifuddin A. Sikap manusia teori dan pengukurannya. Yogyakarta: Pustaka Pelajar Offset. 1995.

24. Vera-Hernández ÁM. Duplicate coverage and demand for health care. The case of Catalonia. Health economics. 1999 Nov;8(7):579-98.

25. Idris H, Satriawan E, Trisnantoro L. The Impact of Health Insurance on Healthcare Utilization Among Those Working in the Informal Sector: Evidence from the National Socioeconomic Survey (Susenas) in Indonesia. Advanced Science Letters. 2017 May 1;23(5):4892-5. 